\title{
Transcription of Cell Wall Mannoproteins-1 gene in Saccharomyces cerevisiae Mutant
}

\author{
Hermansyah \\ Chemistry Dept, Faculty of Mathematics and Natural Sciences, Universitas Sriwijaya Jalan Raya Palembang- \\ Prabumulih KM 32 Indralaya, Ogan Ilir, South Sumatera, Indonesia 30662. Telp. (+62)-711-580269.
}

E-mail: hermansyah@unsri.ac.id

Received: March 2018; Revised: April 2018; Accepted: August 2018; Available Online: November 2018

\begin{abstract}
Protein phosphatase (PPases) are enzymes to catalyze the phosphate groups removal from amino acid residues of proteins by protein kinases. The PPG1, one of PPases in Saccharomyces cerevisiae has less information in function/role. In this research, the disruption of $\triangle P P G 1:: \operatorname{Cg} H I S 3$ in FY833 genetic background was successfully constructed by PCR-mediated disruption strategies using pCgHIS3 (EcoRI-HindIII) (=pYMS314) (pUC19 base) and primer pair of $P P G 1$, forward (41 to 100) and reverse (1048 to 1101). A BamHI - BamHI fragment 3,28 kb $\triangle P P G 1::$ CgHIS3 consisting of $1 \mathrm{~kb}$ upstream PPGI+ $1.78 \mathrm{~kb}$ CgHIS3 + 0.5 down stream of PPGl) was confirmed using PCR and detected using electrophoresis. Phenotypic assay of $\triangle P P G 1:: \mathrm{CgHIS} 3$ in FY833 and did not show $200 \mu \mathrm{g} / \mathrm{ml}$ Calco fluor sensitivity, while another mutant $\triangle P P G 1:$ CgHIS3 in W303-IA show $100 \mu \mathrm{g} / \mathrm{ml}$ congo red sensitivity. Furthermore, to confirm whether $\triangle P P G 1$ could increase a $C W P 1$ transcriptional level was performed Real Time (RT) PCR analysis using Primer pair Kf (AATTCGGCCTGGTGAGTATCC) and $\mathrm{Kr}$ (GTTTCAAAGTGCCGTTATCACT GT). RT-PCR's data showed that transcriptional level of CWP1 in $\triangle P P G 1:: \mathrm{CgHIS} 3$ changed less than two-folds comparing with in wild type strain. This result indicated that disruption of $P P G 1$ in S.cerevisiae did not change CWP1 transcriptional level significantly.
\end{abstract}

Keywords: Saccharomyces cerevisiae, PPG1, CWP1.

DOI: http://10.15408/jkv.v4i2.7367

\section{INTRODUCTION}

Protein kinase phosphorylates other proteins, while protein phosphatase dephosphorylates other proteins, and this phosphorylation is used to activate or inactivate enzyme activity in cells. The reversible phosphorylation of protein is an essential regulatory mechanism that occurs in 
eukaryotic cells. Defect either protein kinase or protein phosphatase resulting in abnormal phosphorylation of protein cause many disease (Zolnierowicz and Bollen, 2000). Some advantages reasons why Saccharomyces cerevisiae used in elucidation of protein phosphatase function as follows: 1) S.cerevisiae is the pre-eminent eukaryote for genetic studies; 2) it intensely genetically has been studied; 3) evolutionarily conserved between yeast and human; 4) Study in S.cerevisiae could reveal important new insights about cellular defects associated with human disease (Hermansyah, 2010).

The PPG1, one of protein phosphatases which have been found, has a few an information from previous studies in its function as well as its role. Therefore, study of some functions of PPG1 referenced from old studies. That protein was not essential for cell growth, but it is described that the PPGl is required for glycogen accumulation through the control of the amount of glycogen synthase (Posas et al., 1993), and required for proper meiosis (Marston, 2004). The $\triangle P P G 1$ disruptant showed opposing phenotype with $\triangle r l m l$ disruptant where deletion of $P P G 1$ and RLM1 were sensitive and resistant to congored, respectively (Hirasaki et al., 2010). Rlm1, a phosphorylated transcriptional activator, is activated by Slt2, a protein kinase that involved in the PKC1-MAPK-signaling pathway regulating cell wall synthesis and the cell cycle (Gustin et al., 1998).

Calco fluor and congo red can inhibit cell wall construction in fungi (Serrano et al., 2006). Calco fluor induces abnormal septa which apparently fail to develop abscission zones between mother and daughter cells
(Roncero and Duran, 1985), a similar effect was produced in S.cerevisiae by congo red (Vannini et al., 1983). The phenotype of inhibited growth by Calco fluor and Congo red has been utilized to screen and isolate cell wall mutants (Ram and Klis, 2006).

CWP1 together with CWP2 are two main genes encoding the cell wall mannoproteins (Van der Vaart et al., 1995). Deletion of both CWP1 and CWP2 genes encoding cell wall mannoproteins markedly increased cell wall permeability, the effects are apparently synergistic, and inactivation of both CWP genes enhances cell staining by Calco fluor white or Congo red (Zhang et al., 2008). Based on these previous references, $P P G 1$ protein phosphatase may have relationship with CWP1 transcription in S.cerevisiae.

\section{MATERIAL AND METHODS}

\section{Strains, Plasmid, and Media}

S.cerevisiae strains used in this study were FY833 with $\mathrm{can}^{\mathrm{r}}=$ MATa ura3-52 his3$\Delta 200$ leu2 $\Delta 1$ lys $2 \Delta 202$ trp1 $\Delta 63$ can $^{\mathrm{r}}$; W303-Ia = MATa ura3-1 leu2-3,112 trp1 his3-11,15 ade2-1; $\quad \triangle P P G 1:: C g H I S 3$ in W303-IA; $\triangle P P G 1:: C g H I S 3$ in FY833 with can $^{\mathrm{r}}$ (NBRP, YGRC or National BioResource Project/Yeast Genetic Research Center, Japan (http://yeast.lab.nig. ac.jp/nig/index_en.html). Oligonucletides used as to construct as follows : PPG1::CgHIS3 disruptant in $p U C 19$. YPAD media was prepared from YPAD broth (SigmaAldrich Co.) with $0.4 \mathrm{mg} / \mathrm{mL}$ adenine. Cultures were cultivated at $30^{\circ} \mathrm{C}$ for $1-2$ days (Hermansyah et al., 2009); 


\section{Construction of $\triangle P P G 1$ disruptant}

PPG1 gene was disrupted by PCRmediated gene disruption as described in previous study (Sakumoto et al., 2002); (Hermansyah et al., 2010). The $\triangle P P G 1$ disruptant were constructed via homologous recombination by integration of gene replacement cassette carrying the $\mathrm{CgHIS3}$ gene. $\quad \mathrm{Kf} \quad\left(\begin{array}{lll}80 & \text { bp }) \quad \text { : } & 5\end{array}\right.$ AGTTACTACCTGAAGTGACTGTA AGGGCACTCTGCTTTAAGCTGAAGGAA ATGCTAGTGACACAGGAAACAGCTATG AC C3'; $\mathrm{Kr}$ (80bp) 5'CTAC AAGAAGTAATCAACATGTCTGTT AGAAGCAGATCTGGCTTGGTATACA TCTGAAAAGTTGTAAAACGACGGCCAG T3'. Confirm insert gene were carried out by PCR amplication using primer pair Kf (30 bp): 5. GGGGGATCCCAGGA ACAGG TTGAGTAGACA 3'; $\mathrm{Kr}$ (30bp) : 5' GGGGGATCCAAATCTCG

AAAGGTCATCGTG 3' by additional BamHI restriction site on 5 both of them. The nucleotide fragment length was detected using $1 \%$ agarose gel electrophoresis.

\section{Yeast Transformation}

Yeast transformation was conducted according to previous study (Ausubel et al., 2003). Cells inoculum grown in YPAD by incubation for $3-4$ hours at $30^{\circ} \mathrm{C}$ with shaking $150 \mathrm{rpm}$ to reach an $\mathrm{OD}_{660}=1.0$. The cells were harvested at $4^{\circ} \mathrm{C}$ by centrifugation, and, after being resuspended into $1 \mathrm{ml} 0.1 \mathrm{M} \mathrm{Pb}$ acetate. Pellet cells was then added $0.24 \mathrm{ml}$ PEG $4.00050 \%$ (w/v), $0.036 \mathrm{~mL} \mathrm{Li} \mathrm{Acetate}$ $1.0 \mathrm{M}, 0.005 \mathrm{ml}$ single strand DNA carrier (10 $\mathrm{mg} / \mathrm{mL}$ ), and $0.070 \mathrm{~mL}$, DNA product $(0.1$ $10 \mu \mathrm{g})$ and sterile water, respectively. Heat shock the mixtures for 25 minutes at $42^{\circ} \mathrm{C}$, and dissolved it in $100 \mu \mathrm{L}$. Spread onto selective media, and incubate the cells at $30^{\circ} \mathrm{C}$ for $2-3$ days until some transformed cells grow as colonies.

\section{Calco fluor and Congo red phenotypic assay}

S.cerevisiae $\triangle P P G 1$ disruptant cells were streaked either on $200 \mu \mathrm{g} / \mathrm{ml}$ Calco fluor containing YPAD agar or $100 \mu \mathrm{g} / \mathrm{ml}$ Congo red containing YPAD agar media. Then, incubated at temperature $30{ }^{\circ} \mathrm{C}$ for 2 days. Sensitive phenotype indicated that $P P G 1$ gen involved in cell wall construction, while resistant phenotype indicated that $P P G 1$ gen did not involve in cell wall construction in S.cerevisiae.

\section{Transcriptional analysis of $C W P 1$}

CWP1 transcriptional level was analyzed using real time PCR as described in previous study (Hermansyah et al., 2009). Both wild type and The $\triangle P P G 1$ disruptant were cultured in YPAD media to reach exponential phase $(\mathrm{OD} 660=1.0)$, and cells were harvested to obtain the cells. cDNA template for quantitative RT PCR was prepared as following steps: RNA of S.cerevisiae strains was isolated using the hot phenol method, and first -strand cDNA was prepared using a high capacity cDNA archive kit (Applied Biosystems). These cDNA samples were used for quantitative RT PCR with a 7300 Real Time PCR system (Applied Biosystems) using primer pair forward: 5'AATTCGGCCTGGTGAGTATCC3' and reverse: 5'ACAGTG ATAACGGCAC TTTGA AAC 3'. 


\section{RESULTS AND DISCUSSION}

In this study, we used some wild type strains FY833 AND W303-1A since they were common yeast strains widely used in yeast genetics. The disruption of $\triangle P P G 1:: \mathrm{CgHIS} 3$ was constructed by PCR-mediated gene disruption as described in Figure 1. PPG1 gene disrupted by integration gene replacement cassete harbouring the CgHIS3 gene (Sakumoto et al., 2002). DNA fragment produced from PCR method were utilized to transform both yeast strains FY833 and W3030-1A. Each primer (reverse or forward primer) used in this study consist of 60 nucleotides of PPG1 and 20 nucleotides of CgHIS3 from plasmid derivated from pUC19 plasmid (Kitada, Yamaguchi and Arisawa,
1995). The $\triangle P P G 1$ disruptants were selected in YPAD media that has no histidine contain (His ${ }^{+}$transformant). By disrupt the whole sequence of PPG1 caused no activity of PPG1 protein phosphatase.

Selected transformants were confirmed by PCR method using primer pair that contains downstream and upstream sequence of PPGl gene open reading frame. PPGl gene located on chromosome XV consist of 1107 nucleotides (Jones et al., 1997). Confirm insert genes were carried out by PCR amplification using primers forward $(-1000$ to -979 ) and (2587 to 2607 ) by additional BamHI restriction site on 5 both of them. A BamHI BamHI of $\triangle P P G 1:: \mathrm{CgHIS} 3$ is of $3.3 \mathrm{kpb}$ consist of $1 \mathrm{~kb}$ upstream $P P G 1+1.8 \mathrm{~kb}$ CgHIS3 + 0.5 down stream of PPG1 as shown in Figure 2.
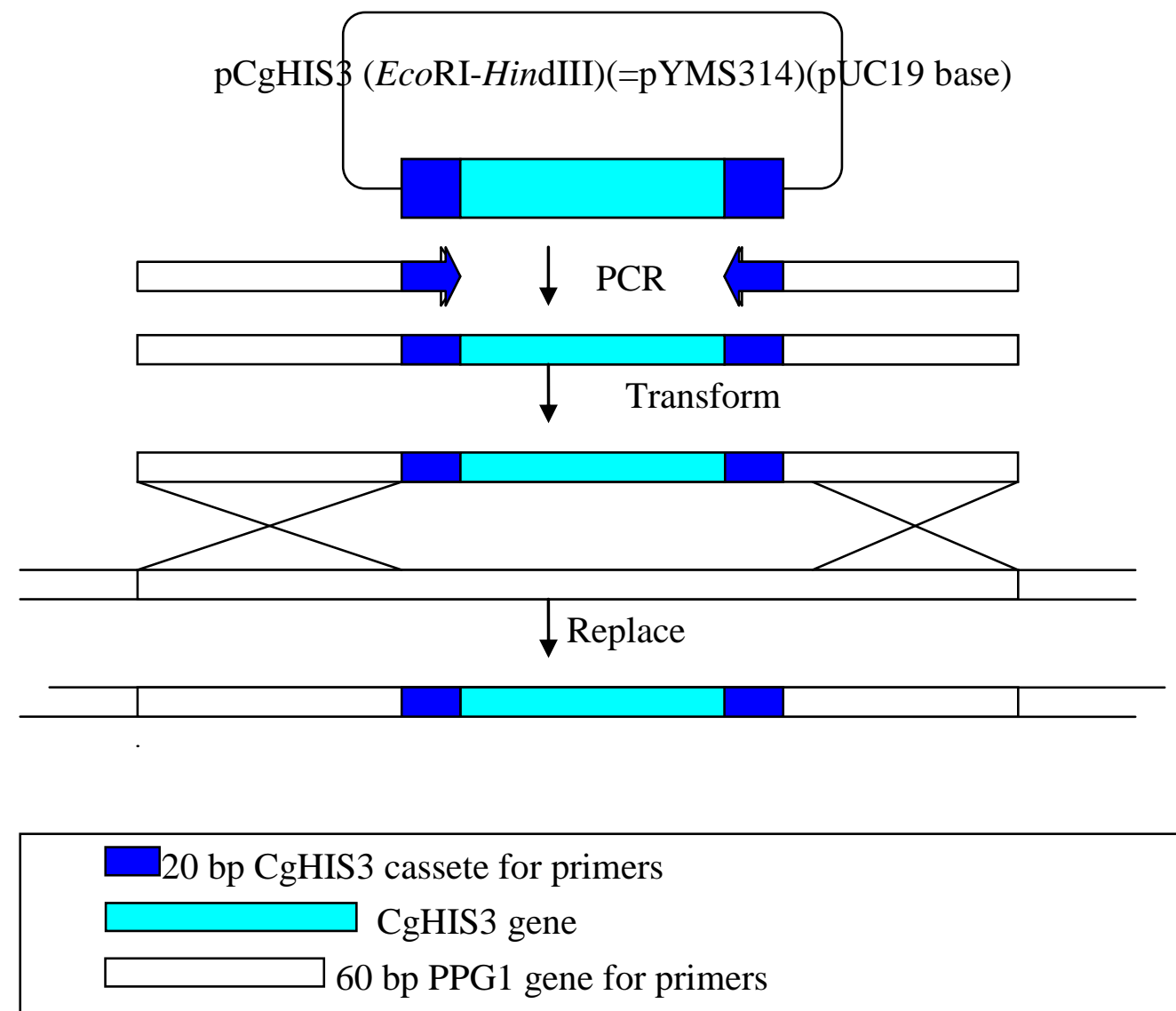

Figure 1. Strategy construction of PPG1 gene disruption by PCR mediated disruption. PPG1 gene disrupted by integration gene replacement cassette harbouring the $\mathrm{CgHIS} 3$ gene. 


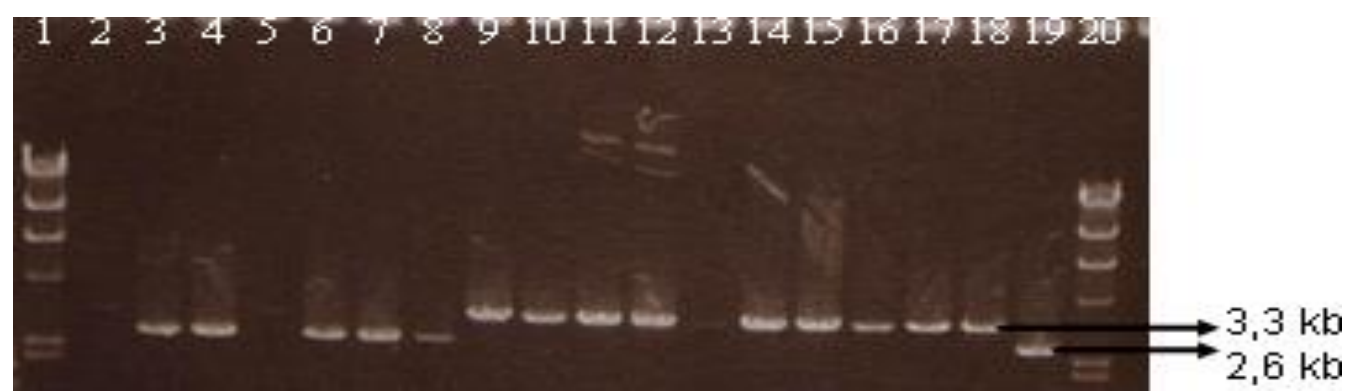

Figure 2. Confirm insert genes were carried out by PCR amplification. PPG gene has been disrupted which confirmed by the presence of DNA fragment 3,3 kb. This indicated that PPG1 gene replaced by CgHIS3 gene.

\section{Phenotypic assay for Calco fluor and Congo red}

YPAD + $100 \propto \mathrm{gg} / \mathrm{ml}$ Congo red

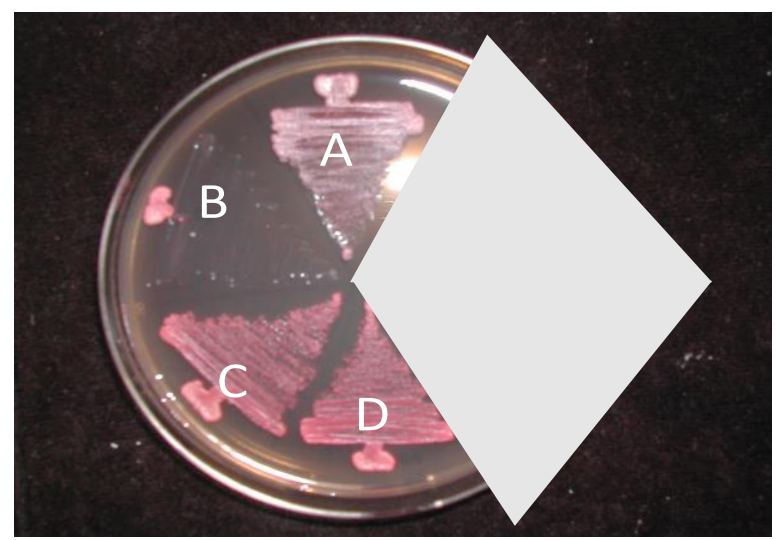

$\mathrm{A}=$ wild type $\mathrm{W} 303-1 \mathrm{~A} ; \mathrm{B}=$

$\mathrm{C}=P P G 1:: \mathrm{CgHIS} 3 / \mathrm{FY} 833$
YPAD + 200॰g $/ \mathrm{ml}$ Calco fluor

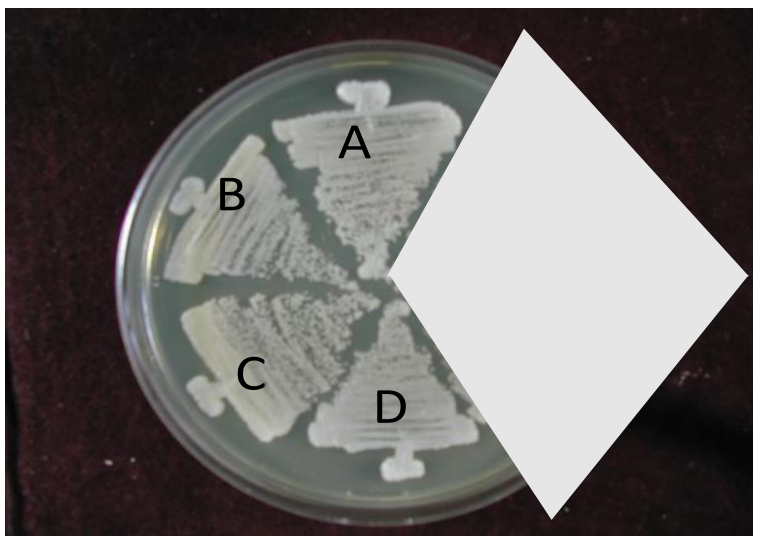

$P P G 1:: \mathrm{CgHIS} 3 / \mathrm{W} 303-1 \mathrm{~A}$;

$\mathrm{can}^{\mathrm{r}} ; \mathrm{D}=\mathrm{FY} 833 \mathrm{can}^{\mathrm{r}}$

Figure 3. Phenotype test on media contains $100 \mu \mathrm{g} / \mathrm{mL}$ congo red and $200 \mu \mathrm{g} / \mathrm{ml}$ calco fluor. The $\triangle P P G 1::$ CgHIS3 in W303-IA can not grow in the presence of $100 \mu \mathrm{g} / \mathrm{mL}$ congo red Congo red, but can grow in the presence of $200 \mu \mathrm{g} / \mathrm{ml}$ Calco fluor.

Both calco fluor and congo red can be used in screening mutants having disrupted gene which play a role in cell wall construction in fungi. Whether effect calco luor or congo red inhibit growth of $\triangle P P G 1$ disruptant, we tested the phenotype of cell growth of $\triangle P P G 1:: \mathrm{CgHIS} 3$ in YPAD in the presence $200 \mu \mathrm{g} / \mathrm{ml}$ calco fluor and $100 \mu \mathrm{g} / \mathrm{ml}$ congo red. The result showed that both $\triangle P P G 1:: \mathrm{CgHIS} 3$ in FY833 and in W303-IA background showed resistant phenotype in YPAD media supplemented with $200 \mu \mathrm{g} / \mathrm{ml}$ calco fluor, while $\triangle P P G 1:: \mathrm{CgHIS} 3$ in W303-IA showed sensitive phenotype to YPAD media supplemented with $100 \mu \mathrm{g} / \mathrm{ml}$ congo red as shown in Figure 3. In previous result, it has reported that the $\triangle P P G 1$ disruptant displayed a clear sensitivity to Congo red and PPGl is involved in the SLT2-pathway which plays an essential role in maintenance of cell shape and integrity in 
S.cerevisiae, and more specifically, it may directly dephosphorylate Rlm1 (Hirasaki et al., 2010). Sensitivity to either calco fluor or congo red has been found as a pleiotropic phenotype associated with certain yeast cell wall mutants since both these drugs have affinity for chitin as minor component of yeast cell wall (Imai et al., 2005).

\section{Transcriptional Analysis of CWP1 by RT PCR}

Since $\triangle P P G 1:: \mathrm{CgHIS3}$ in W303-IA showed sensitive phenotype to YPAD media supplemented with $100 \mu \mathrm{g} / \mathrm{ml}$ Congo red, we analyze furthermore whether this disruption of $P P G 1$ gene induced transcriptional level of CWP1 gene. Together with $C W P 2, C W P 1$ gene encode two major mannoproteins of the outer cell wall (Dielbandhoesing et al., 1998). Yeast cell wall consist of glucans, which constitute the inner layer of cell wall, mannoproteins, which form an external cell wall layer, and chitin (Klis, Boorsma and De Groot, 2006). Another mechanism, a cross talk between the CWI pathway and the signaling networks controlling the aging process might provide more explanation of the complex mechanism of budding (Molon, Woznicka and Zebrowsk, 2018). By using primer pair Kf 5'AATTCGGCCTGGTGAGTATCC3' (71 to 91 of CWP1 sequence) and $\mathrm{Kr}$ 5'GTTTCAAAGTGCCGTTATCACTGT3' (125 to 148 of CWP1 sequence), RT PCR was performed. Based on phenotypic assay result, we analyzed $C W P 1$ gene transcriptional level only pppg1 disruptant in W303 background. In the experiment, optimization of primer usage suggested that both $50 \mathrm{nM} \mathrm{CWPI} \mathrm{primer} \mathrm{and} 50$ $\mathrm{nM}$.

ACT1 primer was better than other concentrations (100 nM, $200 \mathrm{nM}, 300 \mathrm{nM}$ primers) (Data not shown). Thus, both $50 \mathrm{nM}$ $C W P 1$ primer and $50 \mathrm{nM} \mathrm{ACT1}$ were applied to analyze transcriptional level of CWPl in Appg 1::CgHIS3 / W303-IA with two different concentrations, $10 \mu \mathrm{g} / \mathrm{ml}$ DNA sample and 25 $\mu \mathrm{g} / \mathrm{ml}$ DNA sample. RT-PCR data resulted that transcriptional level or gene expression of CWP1 decreased slightly o less than two-fold. This indicate that there is no significant different between $C W P 1$ transcriptional level in wild type and its disruptants (Figure 4).

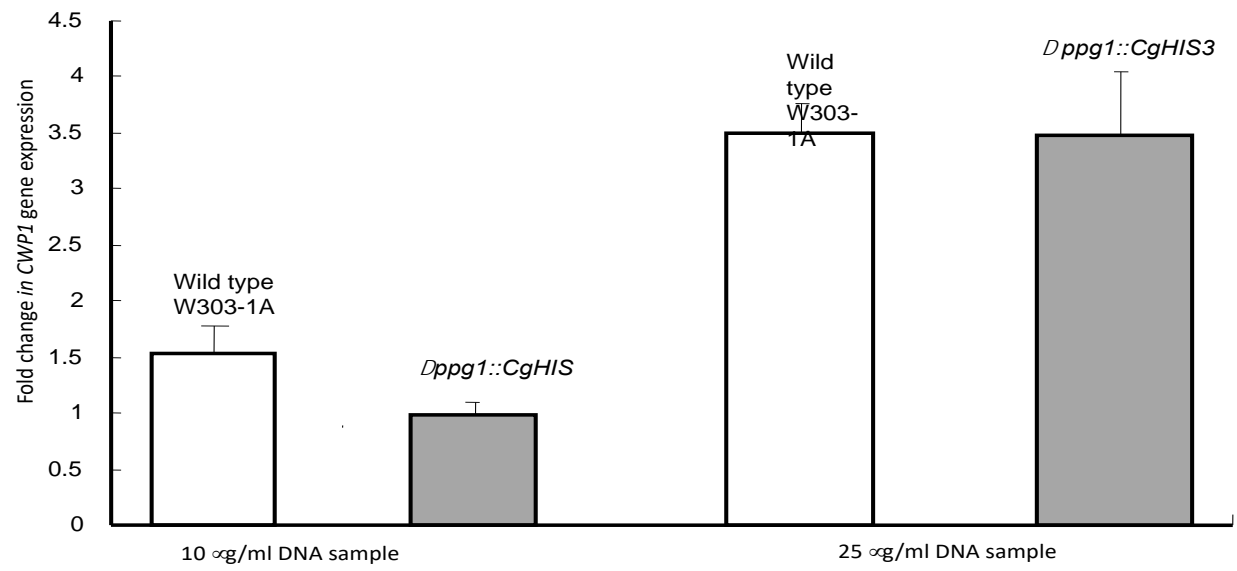

Figure 4. RT-PCR data analyzed transcriptional level of CWP1 in $A p p g 1:: C g H I S 3$ / W303-IA with two different concentrations, $10 \mu \mathrm{g} / \mathrm{ml}$ DNA sample and $25 \mu \mathrm{g} / \mathrm{ml}$ DNA sample 


\section{CONCLUSION}

It has constructed pCgHIS3 (EcoRIHindIII) (=pYMS314) (pUC19 base) and amplified by PCR using primers of PPG1, $\mathrm{f}(41$ to 100) and r(1048 to 1101). A BamHI - BamHI fragment of $P P G 1$ sequence is $2.6 \mathrm{~kb}((1 \mathrm{~kb}$ upstream PPG1+ $1.1 \mathrm{~kb} P P G 1+0.5$ down stream of PPG1). Phenotypic assay of both $\triangle P P G 1:: \mathrm{CgHIS} 3$ in FY833 and $\triangle P P G 1:: C g H I S 3$ in W303-IA did not show $200 \mu \mathrm{g} / \mathrm{ml}$ Calco fluor sensitivity, and only $\triangle P P G 1::$ CgHIS3 in W303-IA show $100 \mu \mathrm{g} / \mathrm{ml}$ congo red sensitivity. Based upon RT PCR`s data showed that transcriptional level of $C W P 1$ in $\triangle P P G 1::$ CgHIS3 comparing with in wild type were less than two-folds changed. This result indicated that no significant different between CWP1 transcriptional level in wild type and its disruptant.

\section{ACKNOWLEDGEMENT}

The author gratefully acknowledges material support to conduct these experiments from Prof. Satoshi Harashima, Prof Yoshinobu Kaneko, and Asc. Prof. Minetaka Sugiyama.

\section{REFERENCES}

Ausubel FM. et al. (2003) Current Protocols in Molecular Biology, Molecular Biology. doi: 10.1002/mrd.1080010210.

Dielbandhoesing SK, Zhang H, Caro LH, Van Der Vaart JM, Klis FM, Verrips CT, Brul S. 1998. Specific cell wall proteins confer resistance to nisin upon yeast cells. Applied and Environmental Microbiology. 64(10):4047-52
Gustin MC, Albertyn J, Alexander M, Davenport K. 1998. MAP kinase pathways in the yeast Saccharomyces cerevisiae. Microbiology and molecular biology reviews: MMBR. 62(4): 1264-1300.

Hermansyah, Sugiyma M, Kaneko Y, Harashima S. 2009. Yeast protein phosphatases Ptp2p and Msg5p are involved in G1-S transition, CLN2 transcription, and vacuole morphogenesis. Archives of Microbiology, 191(9): 721-733.

Hermansyah, Sugiyama M, Lavina WA, Kaneko Y. 2010. Identification of protein kinase disruptions as suppressors of the calcium sensitivity of $\mathrm{S}$. cerevisiae $\Delta \mathrm{ptp} 2 \Delta \mathrm{msg} 5$ protein phosphatase double disruptant. Archives of Microbiology. 192(3): 157-165. doi: 10.1007/s00203-009-0531-6.

Hirasaki M, Nakamura F, Yamagishi K, Numamoto M, Shimada Y, Uehashi K, Muta S, Sugiyama M, Kaneko Y, Kuhara S, Harashima S. 2010. Deciphering cellular functions of protein phosphatases by comparison of gene expression profiles in Saccharomyces cerevisiae. Journal of Bioscience and Bioengineering. 109(5): 433-441. doi: 10.1016/j.jbiosc.2009.10.023.

Imai K, Noda Y, Adachi H, Yoda K. 2005. A novel endoplasmic reticulum membrane protein Rcr1 regulates chitin deposition in the cell wall of Saccharomyces cerevisiae. Journal of Biological Chemistry. 280(9): 8275-8284. doi: 10.1074/jbc.M409428200. 
Jones, M. et al. 1997. The nucleotide sequence of Saccharomyces cerevisiae chromosome XIV and its evolutionary implications. 387(May): 93-98.

Kitada K, Yamaguchi E, Arisawa M. 1995. Of their disruptant strains by sequential integrative transformation. 165: 203-206.

Klis FM, Boorsma A, De Groot PWJ. 2006. Cell wall construction in Saccharomyces cerevisiae. Yeast. 23(3): 185-202.

Marston AL. 2004. A genome-wide screen identifies genes required for centromeric cohesion. Science. 303(5662): 1367-1370.

Molon M, Woznicka O, Zebrowski J. 2018. Cell wall biosynthesis impairment affects the budding lifespan of the Saccharomyces cerevisiae yeast. Biogerontology. Springer Netherlands. 19(1): 67-79.

Posas F, Muns T, Clotet J, Corominas JA. 1993. The gene PPG encodes a novel yeast protein phosphatase involved in glycogen accumulation. Journal of Biological Chemistry. 268(2): 1349-1354.

Ram AFJ, Klis FM. 2006. Identification of fungal cell wall mutants using susceptibility assays based on Calcofluor white and Congo red. Nature Protocols. 1(5): 2253-2256.

Roncero C, Duran A. 1985. Effect of calcofluor white and congo red on fungal cell wall morphogenesis: in vivo activation of chitin polymerization. Journal of Bacteriology. 163(3): 1180-1185.

Sakumoto N, Matsuoka I, Mukai Y, Ogawa N, Kaneko Y, Harashima S. 2002. A series of double disruptants for protein phosphatase genes in Saccharomyces cerevisiae and their phenotypic analysis. Yeast. 19(7): 587-599.

Serrano R, Martin H, Casamayor A, Arino J. 2006. Signaling alkaline $\mathrm{pH}$ stress in the yeast Saccharomyces cerevisiae through the Wsc1 cell surface sensor and the Slt2 MAPK pathway. Journal of Biological Chemistry. 281(52): 39785-39795.

Van der Vaart JM, Charo LH, Chapman JW, KLis FM, Verrips CT. 1995. Identification of three mannoproteins in the cell wall of Saccharomyces cerevisiae. Journal of Bacteriology. 177(11): 3104-3110.

Vannini GL, Poli F, Donini A, Pancaldi S. 1983. Effects of congo red on wall synthesis and morphogenesis in Saccharomyces cerevisiae. Plant Science Letters. 31: 9-17.

Zhang M, Liang Y, Zhang X, Xu Y, Dai H, Xiao W. 2008. Deletion of yeast CWP genes enhances cell permeability to genotoxic agents. Toxicological Sciences. 103(1): 6876.

Zolnierowicz S, Bollen M. 2000. Protein phosphorylation and protein phosphatases. The EMBO Journal. 19(4): 483-488. 